BULLETIN Bulletin hispanique

HISPANIQUE Université Michel de Montaigne Bordeaux

$111-1 \mid 2009$

Varia

\title{
Fama y fortuna de Gustavo Adolfo Bécquer
}

la heterodoxia de las Rimas y el episodio del retrato de la Biblioteca Colombina

\section{Marta Palenque}

\section{(2) OpenEdition}

Journals

Edición electrónica

URL: http://journals.openedition.org/bulletinhispanique/926

DOI: 10.4000/bulletinhispanique.926

ISSN: 1775-3821

Editor

Presses universitaires de Bordeaux

Edición impresa

Fecha de publicación: 1 junio 2009

Paginación: 165-193

ISBN: 978-2-86781-586-7

ISSN: 0007-4640

Referencia electrónica

Marta Palenque, « Fama y fortuna de Gustavo Adolfo Bécquer », Bulletin hispanique [En línea],

111-1 | 2009, Publicado el 01 junio 2012, consultado el 01 mayo 2019. URL : http://

journals.openedition.org/bulletinhispanique/926 ; DOI : 10.4000/bulletinhispanique.926 


\title{
Fama y fortuna de Gustavo Adolfo Bécquer: la heterodoxia de las Rimas y el episodio del retrato de la Biblioteca Colombina
}

\author{
Marta Palenque \\ Universidad de Sevilla - España
}

... de que pasé por el mundo, ¿quién se acordará?

La renommée de Gustavo Adolfo Bécquer s'accroît extraordinairement après la publication posthume de ses auvres, en 1871. Elle fait naître une légende, teintée de sentimentalité, qui infléchit le sens de la lecture. L'un des traits de cette légende concerne l'angoisse et le désarroi vital du poète, dont la foi et l'orthodoxie catholique ont été questionnées même par ses contemporains eux-mêmes. L'article sinterroge sur la prétendue hétérodoxie de Bécquer à l'occasion d'une péripétie bien réelle : l'interdiction, formulée par le chapitre de la cathédrale de Séville, en 1880, de faire figurer son portrait dans la galerie des "Hijos ilustres de Sevilla».

La fama de Gustavo Adolfo Bécquer crece de forma extraordinaria a partir de la publicación póstuma de sus Obras, en 1871, dando lugar a una leyenda de matices sentimentales que ha interferido en el sentido de su lectura. Uno de los rasgos de esta leyenda insiste en la angustia y el desasosiego vital del poeta, de cuya fe y ortodoxia católica dudaron sus propios contemporáneos. Este artículo reflexiona acerca de la supuesta heterodoxia de Bécquer a propósito de una peripecia real: la prohibición del Cabildo de la catedral de Sevilla, en 1880, de que su retrato figurase en la galería de "Hijos ilustres de Sevilla».

Gustavo Adolfo Bécquer won an extraordinary fame, after his "Obras» were posthumously published in 1871, fostering a legend tinged with soppiness that has

$B H i$, Tome $111, \mathrm{n}^{\circ} 1$ - juin 2009 - p. 165 à 193 
interfered with the reading of his work. One of the characteristics of this legend is to emphasize the anxiety and vital uneasiness of the poet - whose faith and Catholic orthodoxy was questioned, even by his contemporaries. This paper deals with Becquer's supposed heterodoxy in relation to a real event: the prohibition, edicted by the Chapter of Seville Cathedral's, to exhibit his portrait in the gallery of the "Hijos Ilustres de Sevilla", in 1880.

Mots-clés : Gustavo Adolfo Bécquer - Hétérodoxie des Rimas - José Gestoso y Pérez - Salvador Sánchez Barbudo - Peinture et littérature.

$\mathrm{R}$ ECUERDa José Gestoso que hacia fines de 1879 o principios de 1880 se colgó en las dependencias de la Biblioteca Colombina, perteneciente a la Catedral de Sevilla, un retrato de Gustavo Adolfo Bécquer obra del pintor gaditano Salvador Sánchez Barbudo, cuadro que, tras diversas vicisitudes, fue retirado muy poco después. Los escritores y artistas sevillanos reclamaron su restitución sin éxito. Una vez devuelto a Gestoso como propietario del mismo, recibió acomodo en la sede de la Sociedad Económica de Amigos del País, de donde no volvió a la Colombina hasta 1909. Este es el resumen desnudo del acontecimiento cuyas causas y circunstancias pretendo desentrañar ahora. La supuesta heterodoxia del poeta fue uno de los argumentos esgrimidos para excluir el lienzo de entre los hijos ilustres de la ciudad que allí se concentraban: los miembros del Cabildo hispalense debatieron sobre el escepticismo becqueriano y su visión materialista de la vida humana. También se dudó del valor de su obra. Pero hay otros y sustanciosos matices que me permiten reflexionar acerca de la fama y fortuna del poeta. Lejos de ser localista, esta historia puede ser extrapolada al ámbito general de la recepción de Bécquer en España y, de hecho, las referencias que usaré van más allá de los límites béticos.

Como simple narración el sucedido no tiene desperdicio y, es más, podría ser base para una novela de libros-ficción de las que ahora tanto gustan: hay hombres rectos atropellados por el sinsentido, sacerdotes taimados e intolerantes, e insinuaciones que parecen ocultar secretos insondables.

Gustavo Adolfo Bécquer muere en Madrid el 22 de diciembre de 1870 . Al día siguiente sus amigos Augusto Ferrán, Narciso Campillo, Ramón Rodríguez Correa y José Casado del Alisal se reúnen y fraguan la idea de 
publicar su obra, para lo que organizan una suscripción ${ }^{1}$. La recopilación de los textos becquerianos dispersos y la recogida de fondos para sufragar los gastos se realiza con rapidez: las Obras de G. A. Bécquer, impresas por Fortanet en dos tomos, están en la calle en julio de 1871 según Pageard. Los estudiosos del poeta manifiestan que la fama de Bécquer nace y se fortalece desde la edición póstuma de este libro. Hasta este año sus rimas y leyendas - cimiento de su popularidad futura- eran conocidas apenas dentro del círculo de compañeros e íntimos ${ }^{2}$, pero las Obras suponen un cambio total en la situación, dando lugar a la "leyenda de Bécquer», al nacimiento de un mito en la historia de la poesía española. Como han señalado Robert Pageard, Ricardo Montesinos, Rica Brown y otros ilustres becquerianistas, la asimilación de Bécquer a un "ser de ensueño» surge a partir de la ordenación de las rimas como reflejo de su vida y, sobre todo, del prólogo de Ramón Rodríguez Correa. De la semblanza del poeta incomprendido y marginado, que pasa todo tipo de privaciones, enfermo, romántico por excelencia, de elevada espiritualidad y escritura espontánea se deriva toda una serie de ensayos en donde el sevillano se alza como un mártir de las letras, casi un nuevo Jesucristo ${ }^{3}$. La edición de 1871 se agotó pronto; se suceden la segunda, en 1877, aumentada y corregida, y la tercera, en 1881. En una «Nota al lector», inserta en la de 1877, Rodríguez Correa afirma: «[E]l que murió oscuro y pobre es ya gloria de su patria y admiración de otros países, pues apenas hay lengua culta donde no se hayan traducido sus poesías o su prosa». Gustavo se ha convertido en modelo de imitación para otros poetas. Sin embargo, este prototipo del romanticismo más tópico (pese a vivir cuando el romanticismo ya se ha extinguido), deviene en poeta fácil, sentimental y anecdótico. Frente a lo planteado por Rodríguez Correa, hay un Bécquer más rico y complejo: esto es algo apuntado por los becquerianistas y no cabe sino seguir el buen camino.

Aunque es la prosa la que despierta un interés más temprano, pronto las rimas son copiadas por sus rasgos originales. Al mismo tiempo, comienzan a ser zaheridas, criticadas y burladas, bien por parecer inadecuadas, e

1. D. Gamallo Fierros, Estudios sobre Bécquer, ed. de Jesús Rubio Jiménez, Zaragoza, 2004, pp. 168-237.

2. R. Pageard (remito a su edición de Rimas, Madrid, 1973) indica que no llega a veinte el número de rimas publicadas en vida del poeta, así como entre su muerte y la salida de las Obras, 1871.

3. Esta comparación es subrayada en ensayos del siglo XX; así en Pedro Marroquín y Aguirre, Bécquer, el poeta del amor y del dolor (Madrid, 1927), Eduardo L. del Palacio, Pasión y gloria de Gustavo Adolfo (Madrid, 1947), o José Andrés Vázquez, que titula «La gloria tras el martirio» uno de los capítulos de su libro Bécquer (Barcelona, 1929). 
incluso perniciosas, para el momento social que atravesaba el país, bien por ser juzgadas amaneradas, falsas y huecas; para sus detractores, muy pronto confundidas con las novedades finiseculares de la naciente época modernista. Esa lectura plana y parcial de Gustavo como poeta del amor y el dolor se extiende por Espańa e Hispanoamérica y se reitera en los remedos humorísticos de sus poemas; Bécquer parece quedar reducido a determinados versos, prosas o retazos de su biografía: el motivo de las golondrinas y la rima LIII, la "pupila azul» de la XXI, el arpa abandonada de la VII, la tumba y el olvido de la LXVI... Escribe Jorge Guillén: "Llega a ser Bécquer el poeta popular por excelencia, el predilecto de las mujeres, y de esas lectoras que buscan, en los versos de amor, no los versos: el amor» ${ }^{4}$. Contribuye a engordar la fama y leyenda de Gustavo Adolfo la popularidad alcanzada por las partituras musicales compuestas para sus poemas en los salones burgueses y aristocráticos del XIX. De una u otra manera, la publicación de Obras (1871) lleva a Bécquer a las alturas del Parnaso en diez años: su público es muy numeroso y la crítica le elogia de forma superlativa.

\section{BÉCQUER HETERODOXO}

Frente a la imagen del Bécquer de una sola cuerda reaccionaron los poetas modernistas y luego los del «grupo del 27» vindicándole como el iniciador de una nueva tradición en la lírica española, hermanándole con Garcilaso de la Vega y destacando sus valores formales más allá del sentimiento. Para ellos Bécquer era "un contemporáneo»" La pujanza y permanencia de las Rimas en toda la poesía moderna es, así, innegable. Hubo, sin embargo, otra rémora que acarreó la leyenda-Bécquer: la supuesta heterodoxia o impiedad del poeta, actitud que evidenciaría el conjunto de su obra y, en especial, sus poemas. Me detengo en la trascendencia de esta acusación porque está en la base de la anécdota que llamo «el episodio del retrato de la Colombina».

La noción del Bécquer heterodoxo es muy temprana y parte también del prólogo de Ramón Rodríguez Correa para las Obras de 1871, quien, al resumir sus líneas de pensamiento fundamentales, denuncia el influjo pernicioso de la religión en la expresión de la inteligencia: «No creo tanto

4. «La fama de Bécquer», en Obra en prosa, ed. de F. J. Díaz de Castro, Barcelona, 1999, pp. 205-207; cita de p. 206.

5. L. Cernuda, Estudios sobre poesía española contemporánea, Madrid, 1975, p. 50. J. Rubio Jiménez refiere las distintas ópticas que la lectura de la obra becqueriana asume a lo largo del siglo XX en Guia sobre los hermanos Bécquer en el Monasterio de Veruela, Zaragoza, 2005, pp. 157-238. 
en la influencia de las razas como en la de las religiones, que, generando las costumbres, preparan una política, una literatura, un arte general dados, los cuales llegan a ser medios en que se desarrollan fatalmente las inteligencias», alega cuando explica las causas del escaso fomento del género de la "poesía subjetiva» que cultiva Gustavo, y carga contra la Inquisición, que impidió el libre vuelo de las conciencias, el avance de la verdad. Todo cambió en su opinión tras la Revolución Francesa: «Las artes resucitaron, el teatro volvió a levantarse, y la poesía lírica, tan perfecta en la forma como en otros días, tuvo por sacerdotes de su culto hombres libres»; surgen en España entonces los versos de Zorrilla o de Espronceda, a quienes continúa Bécquer, al que califica de "revolucionario» ${ }^{6}$. Rodríguez Correa enlaza a Gustavo con Heine o Alfred de Musset, es decir, con el paradigma del poeta rebelde y descreído. Tales apreciaciones van abonando la estampa del vate heterodoxo e impío, peligroso y materialista, en los círculos católicos.

Pueden haber ayudado a consolidar esta lectura aseveraciones como la de Eusebio Blasco, quien, en la necrológica redactada con motivo de la muerte de Valeriano y Gustavo en Gil Blas, el 25 de diciembre de 1870, asegura: "La suerte ha sido despiadada con estos dos artistas que tantas esperanzas hicieron concebir a los amantes de las letras y de las artes. / [...] Dios, ese Dios implacable, lanza su sentencia y todo se acaba. / ¡Vale la pena de creer en Dios para explicar así estas cosas!» ${ }^{7}$ Tampoco esta blasfemia gustaría mucho.

En las reseńas en torno a Bécquer y sus obras aparecidas a partir de 1871 (Pageard y Rica Brown las han coleccionado hasta el límite final del siglo XIX, abundando en el rápido crecimiento de su gloria personal ${ }^{8}$ ) el tema de la religión y la fe sale a colación en varias ocasiones. Amigos y

6. «Gustavo Adolfo Bécquer», prólogo a Obras, Madrid-Imprenta de Fortanet, 1871, t. I, citas de pp. XXVI y XXX. Para R. Pageard (Bécquer. Leyenda y realidad, Madrid, 1990, p. 550), que ha destacado el valor de este prefacio, «debe considerarse el prólogo de Correa como una obra militante y personal».

7. Citado por R. Benítez, «Los hermanos Bécquer en Gil Blas», Insula, 311, octubre 1972, pp. 62-68.

8. R. Pageard, "Bécquer y la vida literaria sevillana», Archivo Hispalense, 174, 1974, pp. 130-135 y «La publicación de las Obras de Bécquer (julio de 1871)», Archivo Hispalense, 177, 1975, pp. 53-69; R. Brown, «La fama póstuma de Bécquer: nuevos datos», Revista de Filología Española, LII, 1969, pp. 525-535 y «The Bécquer legend», Bulletin of Spanish Studies, 18, 1941, pp. 4-18. También J. M. Martínez Cachero, «Donde habite el olvido... (Notas para la fortuna póstuma de Gustavo Adolfo Bécquer)», Cuadernos de Literatura, 1, 2, marzo-abril 1947, pp. 211-227 y «Tres notas para una fortuna póstuma de Bécquer», $B B M P$, XXIII, 1947, pp. 101-104. Me excuso de seguir citando otros títulos sobre la misma cuestión: remito a las bibliografías en torno al poeta sevillano y su obra. 
compañeros (Campillo, Castro y Serrano, por ejemplo) porfiaron en hablar de la melancolía y la tristeza como rasgos predominantes de la sensibilidad poética becqueriana y dieron relevancia en sus comentarios a las Rimas que, según sus pautas, cantaban el desengańo amoroso y la muerte, que pasaron a ser las más citadas y estimadas; otros, sin embargo, tomaron como origen la desesperación y el dolor de las Rimas para dudar de su ortodoxia. Desde las filas católicas tanto desconsuelo resultaba turbio. En un artículo de 1892, Valeriano Barrero Amador alude a una condena publicada en las páginas de La Ilustración Católica que hace explícitas estas sospechas a propósito de una de las rimas más conocidas sobre la muerte, la número LXXIII:

No hace mucho que, leyendo en la Biblioteca Nacional un tomo de La Ilustración Católica, publicado hace ocho o diez años, experimenté honda pena y profundo dolor al encontrar en él un fragmento de la poesía más hermosa de Bécquer, y debajo unas observaciones brevísimas, con las cuales un criticastro que debe tener mucha analogía con el célebre Pedancio, de Moratín, pretendía probar que Gustavo era un poeta frío, cuya cualidad aseguraba que podía demostrarse examinando atentamente la mayoría de los versos que escribió. Yo, que he leído muchas veces todo lo que escribió el poeta hispalense, no puedo menos de levantar mi voz para protestar contra una afirmación tan gratuita, afirmación informada acaso por el misticismo de su autor, que temblaría como la hoja en el árbol al leer algunos versos como éstos, que muchos estiman saturados de escepticismo:

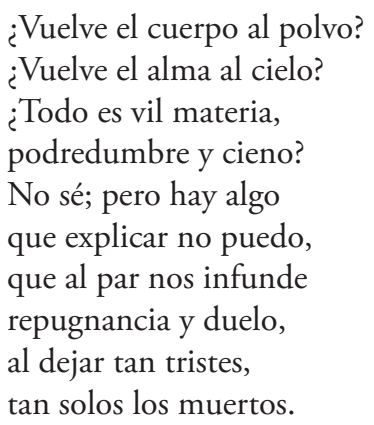

¿En qué funda el colaborador de La Ilustración Católica el calificativo de frío que se permite dar a un poeta de alma tan impresionable y ardorosa? En nada; probablemente en nada: en una manera de juzgar pura y exclusivamente suya; 
en la exagerada susceptibilidad de una conciencia escrupulosa acometida por el vértigo de un miedo horrible? .

Después de revisar varios años de la revista, he localizado el texto que rememora Barrero Amador. Se trata de la paráfrasis de un grabado hecho a partir del óleo de Modesto Urgell ¡Qué solos se quedan los muertos! o un cementerio (núm. 30) el 25 de octubre de 1885. El anónimo redactor lee el cuadro:

Nada más adecuado a los días que vienen, de conmemoración de los fieles difuntos, que el cuadro del pintor catalán Urgell, inspirado en unos melancólicos versos de Becker [sic]. Los versos son, como la mayor parte de las obras de este infortunado poeta, algún tanto fríos, por faltarles el calor de la fe cristiana; sin embargo, Becker, como verdadero artista, como verdadero poeta, era a veces cristiano sin saberlo, por la fuerza espontánea de su inspiración, y no es difícil hallar en sus composiciones sentimientos tiernos y delicados, propios de corazones creyentes.

Copia a continuación la rima que inspiró a Urgell, y añade: «Falta en la composición de Becker el calor que comunica la fe a la frialdad de los sepulcros, sobre los cuales columbra el cristiano la luz inefable de la esperanza y de la resurrección». Compara el sentimiento de la muerte en Bécquer, tal y como él lo percibe, con el de Jorge Manrique, y acaba: «La muerte es fría y horrible para el incrédulo, que no ve más que tierra en un campo santo: pero está llena de consuelos y de esperanzas para el cristiano, que ve el campo santo poblado de cruces, que brotan como flores de resurrección de aquella tierra consagrada con los restos mortales del hombre, hijo de Dios, hecho a su imagen, y heredero de su gloria eterna ${ }^{10}$.

En cuanto a la rima objeto de litigio, ahora empleada para probar la impiedad becqueriana, es una de las más difundidas; su estribillo ( ¡iDios mío, qué solos / se quedan los muertos!») gusta mucho en las parodias de la prensa de humor (en Gedeón, a la altura del 9 de diciembre de 1906, se transforma en «iDios mío, qué solos se quedan los vivos!» en una caricatura de Segismundo Moret). Esta notoriedad la refrenda y acentúa Marcelino

9. «Gustavo A. Bécquer. Estudio crítico biográfico», publicado de forma fragmentada en Revista de España a partir de enero de 1892. Utilizo la entrega correspondiente al t. CXLI, 562, pp. 391-392.

10. P. 351; el grabado está en la p. 355. Con respecto a La Ilustración Católica, Marta Bizcarrondo, "La Ilustración Católica: Los inicios del nacionalcatolicismo", en La prensa ilustrada en España. Las «Ilustraciones», 1850-1920, Montpellier, 1996, pp. 303-312. 
Ménendez y Pelayo al seleccionarla más tarde en Las cien mejores poesías (líricas) de la lengua castellana (1 ${ }^{\mathrm{a}}$ ed. 1908).

Junto a las Rimas, las Cartas desde mi celda fueron asimismo citadas como referente en notas críticas en torno a la religión y la fe. Así, Benito Pérez Galdós («Las Obras de Bécquer», 1871) apuntaba: «La carta tercera, la mejor de todas y una de las más sobresalientes obras de nuestro autor, es una meditación cristiana e impregnada del doble idealismo de la religión y la poesía», y luego, cuando pasa a discernir acerca de las ilusiones tronchadas del artista que ha de sucumbir a las necesidades materiales de la existencia:

El hombre de inteligencia superior que como el pobre Bécquer se ve en este trance, ha de incurrir o en un amargo escepticismo de religión y de arte o ha de sentirse interiormente corroído por una melancolía profunda y devastadora que mata todos los días un poco, como los cánceres. En tal situación de espíritu las almas que no pueden ser escépticas como la de Gustavo, tienen necesariamente que dejarse ir, arrastradas por esa tendencia, nacida y desarrollada en su interior, al aniquilamiento y al olvido ${ }^{11}$.

También las leyendas fueron juzgadas un poco culpables. El sevillano Rafael Álvarez Sánchez Surga redacta, el 25 de abril de 1872, una breve reseña en la que, una vez destaca la edición de las Obras como el evento literario más importante del año 1871, evalúa negativamente las Rimas y dice preferir las Leyendas, en las que no obstante encuentra matices heterodoxos: «[T]odas ellas están tomadas del pueblo o calcadas en sentimientos populares, y en todas ellas predomina la fantasía y el sentimiento religioso, aunque saliéndose alguna vez de la ortodoxia católica» ${ }^{12}$.

11. Los Debates, 13 noviembre 1871; en R. P. Sebold ed., Gustavo Adolfo Bécquer, Madrid, 1985, pp. 61-71.

12. Artículo incluido en Revista Mensual de Filosofía, Literatura y Ciencias (Sevilla); luego en Obras (Sevilla, 1873, pp. 250-253); cita de p. 251. Sánchez Surga glosa en el mismo lugar el volumen La Pereza, de Augusto Ferrán, indicando: «Un prólogo de Béquer avalora aún más esta perla literaria». El número citado de la Revista Mensual de Filosofía, Literatura y Ciencias está dedicado a homenajear a Álvarez Sánchez Surga, recientemente fallecido, por lo que se procede a reproducir varias de sus obras, entre ellas poemas originales en los que se advierte su conocimiento de la poesía alemana: en concreto una balada, una imitación de Heine y un cantar. El contacto con lo becqueriano es evidente: «Si en el desierto triste peregrino / oye a lo lejos el Simún bramar / y un oasis no encuentra en su camino / ¿A dónde iré a parar? / Frágil esquife que en la mar bravía / persigue el inmenso navegar / sin brújula, timón, norte ni guía / ¿A dónde iré a parar? [...]». 
¿Hasta qué punto no ofendieron también a los católicos, por su equiparación a la figura de Cristo, las alusiones al martirio de Bécquer o a la corona de espinas que, como única recompensa, recibió su genio? Incluso su moralidad estuvo en entredicho (ya Correa afirmó que la única moral a que debe rendirse el poeta es la belleza de su arte): instauradas las Rimas como lectura femenina, fueron estimadas poco adecuadas para tan tiernos corazones (y más débiles mentes, a juicio de la época). Julia Bécquer cuenta en sus memorias que sus tíos y tutores, Estanislao Bécquer y su mujer, Adelaida Cabrera, la enviaron a educarse al pensionado del Sacré Cour pero la mantenían ignorante de las obras de Gustavo, "pues a mi tía doña Adelaida, señora muy culta y artista, pero educada a la antigua, no le había parecido conveniente dármelas a conocer. En cambio, condiscípulas mías, de más y de menos años que yo, me hablaban callandito en el estudio de sus rimas y leyendas con entusiasmo" ${ }^{13}$.

Muestras de la existencia de un clima de opinión en torno a la supuesta impiedad becqueriana, en otros lugares se leen reflexiones variopintas que tanto salvan al poeta como le arrojan a los abismos del infierno. Para el anónimo G., que firma una temprana reseña de Obras en 1871 (Revista de España), su desesperación no presupone falta de fe: «A pesar de su humor hipocondríaco y negro, Bécquer no es escéptico, y aunque su fe no sea del todo ortodoxa, la fe existe en él, sobre todo cuando busca con la fantasía en desconocidas regiones un sitio para su espíritu y un hoyo para su cuerpo». A favor de la salvación de su alma aboga Francisco Blanco García, exculpándole de las acusaciones de escepticismo e irreligiosidad que sí merece en su opinión Heine, cuya posible influencia en las rimas se esfuerza por apartar, al tiempo que señala (muy oportunamente) como base de la "poesía subjetiva» becqueriana a Fray Luis y San Juan de la Cruz ${ }^{14}$. Becquerianistas contemporáneos (Pageard, Brown, Montesinos...) han argumentado en contra del escepticismo becqueriano a partir de los propios textos ( $\mathrm{Se}$ comprende que el prólogo de Correa incitara a críticos más conservadores a leer las Obras con particular vigilancia en el plano religioso. Sin verdadero fundamento. Tuvo Bécquer sus momentos de desilusión y descorazonamiento pero no puso nunca seriamente en tela de juicio la fe que le había inculcado su madre y la sociedad sevillana que le rodeaba, hermanándose esto con la

13. «La verdad sobre los hermanos Bécquer. Memorias de Julia Bécquer», Revista de la Biblioteca, Archivo y Museo del Ayuntamiento de Madrid, 33, enero 1932, pp. 76-91; cita p. 91.

14. Tomo la cita del anónimo G. de Pageard, "La publicación de las Obras de Bécquer...", art. cit., p. 57. Blanco García, La literatura en el siglo XIX (Parte segunda) [1891], Madrid, 1910 (3a ed.), pp. 82, 86-89. 
independencia de su carácter», perfila Pageard) ${ }^{15}$. En Bécquer tradicionalista, Rubén Benítez advierte de su talante contradictorio en lo relativo al progreso social, pero subraya su interés por la tradición y su preocupación devota ${ }^{16}$.

Dionisio Gamallo Fierros fue más allá e intentó averiguar si Gustavo recibió auxilios espirituales en su lecho de muerte, aunque no pudo obtener declaraciones concluyentes. Le sorprende el silencio que guardan los amigos del poeta en este extremo, así como en todo lo concerniente a su práctica religiosa. Intrigado, analizó su obra bajo esta luz, citando ejemplos de su fe extraídos de la introducción a la Historia de los templos de España (labor por la que llegaría a ser calificado de «neocatólico»), la carta IX de Desde mi celda, varias de sus leyendas, etc., pero no se pronuncia de forma absoluta: los pesares vitales pudieron empujarle hacia un cierto descreimiento, remata. No abundo en otras tesis de similar sentido ${ }^{17}$.

Desde una óptica matizada y distinta, la idea de un Bécquer materialista ha sido estudiada en relación con la modernidad de su poética (Urrutia, De la Peńa). Russell P. Sebold expone que el escepticismo becqueriano es testimonio de esta modernidad y con tal criterio repasa la presencia del pensamiento materialista en las leyendas y las rimas ${ }^{18}$. No cabe duda

15. Pageard, Bécquer. Leyenda y realidad, op. cit., p. 550.

16. Bécquer tradicionalista, Madrid, 1970, p. 31 y ss.

17. Gamallo Fierros, op. cit., pp. 155-168. Gamallo proyectaba el ensayo Ideas y sentimientos religiosos de Gustavo Adolfo Bécquer, que, por lo que sé, no llegó a ver la luz. Sumo otros testimonios en los que se insiste en dejar libre de duda la fe de Gustavo: M. R. BlancoBelmonte redacta una breve ficción en torno a la estatua de Bécquer sita en el Parque de María Luisa de Sevilla y cuenta cómo la glorieta es espacio de culto y oración para sus admiradores. Entre los que allí acuden está un «Prelado misionero», quien bendice la escultura y se vuelve a los sacerdotes que le acompañan para decirles: «Vivió como católico; si pecó, supo arrepentirse de su yerro, y murió en el seno de nuestra Santa Religión, besando un crucifijo» («Bajo las ramas de un cedro descansa la imagen del poeta», Blanco y Negro, 16 de febrero de 1936 [p. 7]). Eduardo del Palacio (Pasión y gloria de GAB, Madrid, 1947, cap. XXIV): "Siente como pocos la unción en la presencia divina (véase la carta IX), de la devoción de la Cruz (carta V), la creencia en la inmortalidad del alma (carta II)». M. García Viñó sostiene que su obra demuestra la gran capacidad hispana hacia lo trascendente y señala en concreto varias rimas y leyendas (destaca Creed en Dios); además, repasa las menciones que hay en su obra a la fe, los milagros o temas religiosos; también hubo dudas, termina, y su producción lo expresa, lo que para él subraya la profunda honestidad del poeta, en ningún caso su ateísmo o impiedad, «La religión de Bécquer», Razón y Fe, 181, enero-junio 1970, pp. 61-68 (del mismo autor, El esoterismo de Bécquer, Sevilla, 1991).

18. J. Urrutia, «¿Bécquer ¿Poeta materialista?», BRAE, 57, mayo-agosto 1973, pp. 399-410; P. J. de la Peña, Las estéticas del siglo XIX, Valencia, 1994, pp. 52-68; Sebold, «Introducción» a su edición de Rimas, Madrid, 1989, pp. 19-34. Sebold continúa con este planteamiento en la entrada relativa a las Rimas en Historia de la literatura española. Siglo XIX (I), Víctor García de la Concha, dir., Leonardo Romero Tobar, coord., Madrid, 1998, pp. 255-273. 
acerca del atractivo -y la cercanía- de esta lectura para los poetas de los siglos XX y XXI.

Menor importancia tienen hoy la fe o la irreverencia de los poetas para calibrar su calidad y autorizarles o negarles la entrada en los confines de la fama; pero en tiempos donde sí era una cuestión principal, los escrúpulos y las suspicacias se cernían sobre la obra becqueriana.

Conviene insistir en otros extremos (en parte coincidentes con los ya formulados) de la construcción del «ser de ensueño». Como es sabido, los amigos y editores de las obras becquerianas tanto interpretaron como eludieron aspectos de la biografía del poeta. Rubén Benítez se ha detenido en ello a propósito de la adscripción ideológica de Gustavo al moderantismo de Luis González Bravo y su presencia en la política activa: «los amigos participaron en una doble y contradictoria responsabilidad: por un lado fijaron preciosos datos sobre su vida y difundieron sus escritos; por el otro, silenciaron todo aquello que pudiera empañar una imagen deliberadamente idealizada ${ }^{19}$. Su empleo como censor de novelas es una de las parcelas de su biografía sobre la que pasaron casi de puntillas. Es interesante recordar que este cargo situaba a Bécquer en el papel de protector de la religión y la moral conservadoras, oficio que, en opinión de los «neocatólicos» o carlistas, no ejerció siempre con acierto y, así, recibió ataques en 1868 desde este frente por permitir la publicación del folletín El señor de Camors, de Octavio Feuillet ${ }^{20}$. Benítez afirma la asimilación de los escritos becquerianos al credo del conservadurismo moderado, con los que casaba bien su intento de conciliación entre lo viejo y lo nuevo, y además pondera su posible relación con la masonería por usar símbolos de esta procedencia en «La mujer de piedra». Concluye que, a partir de su amistad con González Bravo, ese calificativo de «neocatólico» que algunos le colocaron en 1860 por la Historia de los templos de España (donde se muestra heredero del tradicionalismo francés) ha quedado atrás ${ }^{21}$, lo que explicaría la animadversión hacia su persona y obra. Las agresiones de la prensa católica revestirían así un doble sentido: no solo serían una condena religiosa, sino también una ofensiva política (pese a los muchos ańos transcurridos entre la muerte de Bécquer y los artículos mencionados).

19. Bécquer tradicionalista, op. cit., p. 22.

20. Sus amigos le defendieron: Rubén Benítez, «El periódico Gil Blas defiende a Bécquer, censor de novelas», Hispanic Review, XXXVI, enero 1968, pp. 35-43.

21. Bécquer tradicionalista, op. cit., pp. 37, 39 y 40. 


\section{Un cuadro para la Biblioteca Colombina}

Al episodio del cuadro de la Colombina se ha hecho referencia en varios lugares, a veces con cierta superficialidad. José Andrés Vázquez y Rafael Montesinos (quien reproduce el retrato) le han dedicado una mayor atención, aunque el relato más preciso y documentado lo realiza Juan Guillén en una reciente Historia de las Bibliotecas Capitular y Colombina ${ }^{22}$. En coincidencia con este último, narro el suceso con base a las noticias aportadas por José Gestoso y Pérez y a las Actas Capitulares del Cabildo de la Catedral hispalense, que ofrecen versiones complementarias.

El joven Gustavo Adolfo Bécquer dejó Sevilla en 1854 para buscar nuevos horizontes en Madrid, pero añoró siempre su ciudad y la transformó en motivo lírico y espacio para narraciones tales como Maese Pérez el organista o La Venta de los Gatos. También reflexionó acerca de sus costumbres y tradiciones, de su poesía popular y el folklore ${ }^{23}$. Para los jóvenes poetas sevillanos de finales del XIX su figura aparece agigantada: por un lado, es el hermano que abandonó su tierra para intentar el triunfo en la capital y que, atravesando sinsabores y desprecios, logró llegar a la cima; por otro, es el defensor de la poesía popular andaluza, el introductor de una poética nueva, que muchos siguen y remedan. Se puede sumar una postrera: la obra de Bécquer había colocado una piedra más en la elevación de la ciudad del Betis, celebrada en la literatura, sitio de historia y nobleza, que ahora el hijo pródigo retoma y reverdece.

Desde la muerte de Gustavo Adolfo Bécquer hay en Sevilla un cierto clima de rehabilitación de su memoria que se ejerce en la conciencia de la necesidad de rendir justicia a un poeta que, se repite, tanto sufrió en vida y cuya gloria le alcanzó en la tumba. El suelo que le vio nacer, y cuya fama ha crecido gracias a su inspiración, le debe algún testimonio de su amor y de su agradecimiento, insisten. La reputación de Sevilla y la de su esclarecido vástago debe brillar a una misma altura. Se inician así una serie de proyectos con el destino de honrarle y estrecharle a la cultura bética.

Entre las empresas contempladas para culminar este deseo, el cuadro que debía figurar entre los sevillanos ilustres de la Biblioteca Colombina es el primero en el tiempo. También se planearon otras tareas: ofrendarle una estatua, rotular con su nombre una calle, señalar con una lápida la casa en

22. Vázquez, Bécquer, op. cit., pp. 137-139; Montesinos, Bécquer. Biografía e imagen, Sevilla, 2005, pp. 9 y 334; Guillén, Historia de las Bibliotecas Capitular y Colombina, Sevilla, 2006, pp. 475-477.

23. Al respecto R. Reyes Cano, Sevilla en la obra de Bécquer, Sevilla, 2000 (2a ed.). 
que nació y, tal vez el más importante, trasladar sus restos desde Madrid. Estos trámites o bien se demoraron largos años o se llevaron a cabo poco satisfactoriamente. Por lo que permiten entender los escasos datos que aparecen en la prensa sevillana hasta los años ochenta y las explicaciones de los sujetos que intentaron cumplir estos deseos, la recepción de Bécquer en Sevilla enfrentaba a la juventud estudiosa con el escaso interés de los gobernantes y los prejuicios de la Iglesia y los sectores más conservadores. Así lo afirma José Gestoso y Pérez (Sevilla, 1852-1917), uno de sus principales valedores en Sevilla, admirador rendido de su obra, quien se cuenta entre los promotores de cuantas iniciativas se organizaron en su beneficio; de él fue la idea del retrato con destino a la Colombina, cuya galería juzgaba el emplazamiento idóneo para situarlo. Licenciado en Derecho, archivero bibliotecario y anticuario, persona de gran cultura, Gestoso fue también poeta ocasional y publicó cantares en las revistas sevillanas y algunas tempranas imitaciones de las rimas, que en sus manuscritos están fechadas desde enero de 1872, ratificando el hondo poso que la lectura de las rimas dejó en sus compatriotas ${ }^{24}$. A su primorosa colección de papeles incorporó varios documentos sobre la familia Bécquer, lo que repite en sus carpetas de autógrafos, donde hay tres cartas de igual origen ${ }^{25}$.

Retomando el hilo de lo resumido al principio, cuenta Gestoso que él actuó como gestor en todo lo relacionado con la elaboración del lienzo -que encargó a Salvador Sánchez Barbudo-, aunque de acuerdo con el oficial de la Colombina, José Ma Fernández y Velasco (ocupó su puesto de 1832 a 1879; fallece en diciembre de este último año), y el capitular bibliotecario, Evaristo de la Riva (nombrado en julio de 1879). A Fernández Velasco se debe el engrandecimiento de la galería pictórica colombina desde 1870 (y en ello colaboró con Juan José Bueno, regidor del Ayuntamiento, jefe de la Biblioteca Provincial Universitaria y bibliófilo) entre otros trabajos que supusieron, en palabras de Juan Guillén, la resurrección de la librería catedralicia. El lugar elegido para Bécquer era de gran importancia al tratarse de una biblioteca de gran renombre, principal monumento de la cultura y símbolo de la gloria sevillana por cuanto remitía a la gesta Colombina y a la edad dorada de la ciudad. La colección colombina se había iniciado hacia finales del siglo XVII y la componían tres secciones distintas: Arzobispos de la Diócesis, Hijos ilustres de Sevilla e Hijos célebres de la provincia. El afán

24. José Gestoso, Papeles Varios, II, fols. 209 y 362-364, tomos manuscritos conservados en la Biblioteca Capitular de Sevilla (Institución Colombina).

25. Cartas suscritas por Gustavo, José Bécquer y Joaquín Domínguez Bécquer; las transcribo y comento en «El autógrafo de la carta de Gustavo Adolfo Bécquer a Juan José Bueno y otras epístolas relativas a su familia» (BBMP, enero-diciembre 2008, pp. 239-261). 
BULLETIN HISPANIQUE

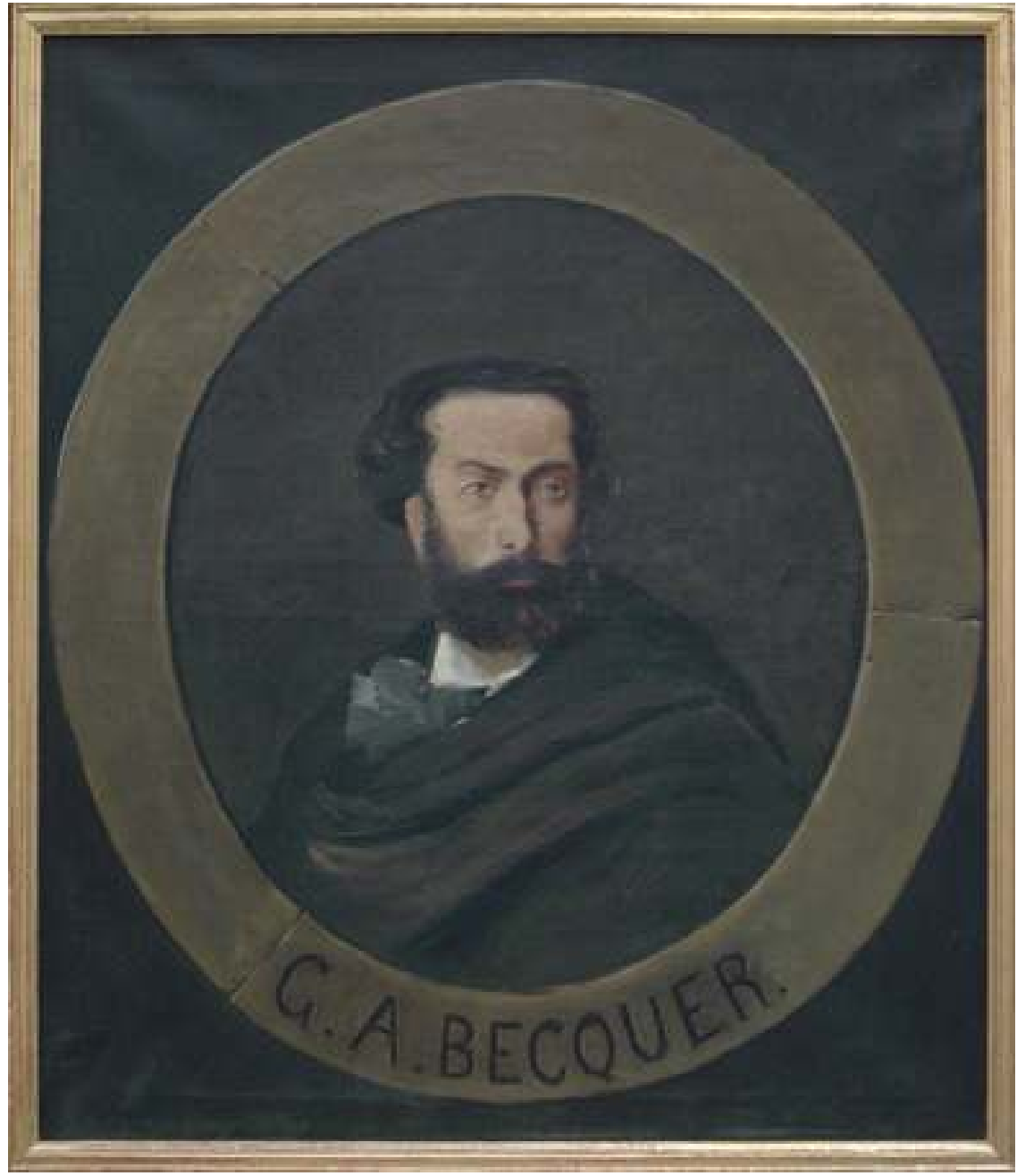

Retrato. «Gustavo Adolfo Bécquer», por Salvador Sánchez Barbudo (Biblioteca General, Universidad de Sevilla) 
de la burguesía decimonónica por crear y afianzar sus señas de identidad como clase va a acentuar el interés por estos recuerdos del pasado nacional en pinturas y esculturas. En la Colombina se fueron congregando imágenes de personajes notables: Rodrigo Ponce de León, Pedro Mexía, Lope de Rueda, Juan de Malara, Fernando de Herrera, Francisco Pacheco, Mateo Alemán, Gonzalo Argote de Molina, Juan de la Cueva, Juan de las Roelas, Juan Martínez Montañés, Fernando Afán de Rivera, Gerónimo Hernández, Diego Velázquez, Francisco de Rioja, Fernando de la Torre, Bartolomé Esteban Murillo, Nicolás Antonio, Miguel de Mañara, Juan de Valdés Leal, Manuel María del Mármol, Félix José Reinoso, Alberto Lista, Antonio Cabral Bejarano (maestro de pintura del joven Bécquer), Gabriel García Tassara, Antonio María Esquivel... Hacerle comparecer junto a sus maestros y en compañía tan selecta era el mejor homenaje que se le podía tributar a Gustavo Adolfo Bécquer. En la sala correspondiente a «Hijos célebres de Andalucía» se fueron agregando las efigies de Arias Montano, José Fernández Espino, El Gran Capitán, Alonso Cano, Antonio de Nebrija, el Marqués de Santillana... ${ }^{26}$ En Sevilla hubo otras galerías de similares características en la Biblioteca Universitaria y en el palacio del Duque de Montpensier (ésta pasó luego al Ayuntamiento).

Gestoso contó la historia del retrato becqueriano de varias guisas: ora es sugerente y sesgado, ora directo y preciso, anotando nombres y apellidos. Este segundo camino es el que elige en un manuscrito conservado en la Biblioteca Capitular de Sevilla, que prefiero como fuente primordial:

A fines de 1879, o en los comienzos del 80, regalé al Cabildo Catedral un hermoso lienzo representando el busto del ilustre poeta. Era oficial de aquel Establecimiento el inolvidable D. José $M^{a}$ Fernández y Velasco, restaurador de las grandezas de la Colombina, y bibliotecario en nombre del Cabildo, D. Evaristo de la Riva, sujeto tan virtuoso como escaso de conocimientos y que se dejaba traer y llevar por unos y por otros. De acuerdo con el Sr. Fernández, pedí a mi amigo el pintor Barbudo me pintase el retrato del inmortal poeta, para que figurara entre los hijos ilustres de Sevilla: accedió gustoso, hízolo, fue llevado a la Colombina, y se le dio puesto entre los demás. El intolerante jesuita P. Moga, que por estos días había venido a Sevilla

26. F. Collantes de Terán ofrece una relación de las piezas incorporadas a esta galería hasta 1887, "Galería de retratos de sevillanos ilustres que se conserva en la Biblioteca del Excmo. e Ilmo. Cabildo", Archivo Hispalense, III, 1887, pp. 169-176 y 234-241. En esta lista no se menciona el retrato de Bécquer, ya descolgado en la fecha de redacción del catálogo. 
para hacer propaganda carlista, quiso hacerme prosélito de su causa, pidiéndome un artículo encomiástico del Centenario de Murillo, pretexto con que encubría sus móviles, yo se lo negué y él, que iba frecuentemente a la Colombina, cuando supo que yo había regalado el cuadro de Bécquer, hizo mil protestas a D. Evaristo de la Riva y le calentó los cascos, diciéndole que allí no debía tolerarse más que retratos de sevillanos ilustres católicos y ortodoxos a carta cabal; el bueno del bibliotecario se alarmó, y considerando que el dogma y la disciplina de la Iglesia peligraban de continuar el lienzo expuesto al público, mandó que lo bajasen y escondieran donde no le llegase la luz ${ }^{27}$.

Cuando supo la noticia, Gestoso convocó a los más destacados representantes de la prensa y de las artes hispalenses para reclamar una rectificación. Con tal fin redactaron el documento que sigue:

Los que suscriben deseosos de honrar la memoria del ilustre escritor Gustavo A. Bécquer a V. E. I. suplican se digne disponer la colocación de su retrato entre los de sevillanos ilustres que ornan los muros de la Biblioteca Colombina. Petición que esperan será atendida dado el reconocido saber de V. E. I. Sevilla, 14 de agosto de 1880. Por El Alabardero, Juan P. Pérez Gironés. Por El Universal, José Azabal. Por Los Debates, José María Manella. Fernando Belmonte. Francisco de P. Ramos. Narciso Sentenach. Por El Porvenir, Federico Piñal. Por El Mercantil Sevillano, Celedonio de Salas. Por la Academia Libre de Bellas Artes, Joaquín Turina, José Jiménez Aranda, Manuel Jiménez y José Villar Sánchez. Virgilio Mattoni. Ricardo Sanjuan. Eduardo Cano. Carlos Jiménez Placer. Joaquín Guichot. José Shez. [sic] Arjona. Rafael Cebreros y Bueno. Felipe Pérez y González. Gonzalo Segovia y Ardizone. Ildefonso de Cańaveral. Francisco José Barnés. Manuel de los Palacios y Fagúndez. Mario Méndez Bejarano. Antonio Machado y Núńez. Javier Lasso de la Vega y Chidón. Por La Gaceta Comercial, Isauro López Ochoa. Luis Montoto. José Gestoso. José de Chaves. José Díaz Valera. Manuel Wssel. José de Velilla. B. Mas y Prat. José Velarde. Luis Escudero y Perosso. Mariano Caso. Anselmo R. de Rivas. José Ma del Campo. Juan Maíllo y Martín. Maximino Ruiz Díaz.

27. De historia sevillana. Páginas de mi vida 1878-191, sign. 114-6bis-8, hs. 85-110; cita hs. 85-86. Agradezco a Nuria Casquete de Prado, directora de la Institución Colombina, que me diera a conocer este documento. 
Claudio Boutelou. Federico de Castro. Manuel Cano y Cueto. Por La Enciclopedia, Federico Barbado. Leoncio Baglieto. José Villegas (hs. 87-88).

Ciertamente, entre los firmantes de la petición se encuentran nombres conocidos de la opinión pública hispalense, además de profesores y ensayistas (Federico de Castro, Antonio Machado y Núñez, Mario Méndez Bejarano, Joaquín Guichot...), músicos (Turina, Rafael Cebreros), pintores (Jiménez Aranda, Virgilio Mattoni, Eduardo Cano, Wssel, Villegas...), escritores (Luis Montoto, Cano y Cueto, Velarde, José de Velilla, Felipe Cano...), etc. Gonzalo Segovia (luego presidente de la comisión que luchó por el traslado de los restos de Gustavo y Valeriano a Sevilla) y Eduardo Cano ayudaron económicamente a la edición de las Obras de Gustavo en 1871, cuya suscripción tuvo como domicilio el estudio del segundo. Pero el Cabildo siguió su propio criterio y no cambió el dictamen:

Confiaba yo en que el Cabildo pararía mientes en este asunto al ver que los firmantes de la exposición representaban la Sevilla culta, puesto cuanto notable había entonces en ella en las artes y en las letras acudió al llamamiento que hice; sin embargo, a consecuencia de esto, alzóse gran marejada y los sectarios del P. Moga propalaban, urbi et orbi, la heterodoxia, la impiedad y el escepticismo del gran poeta. Entonces adoptó el Cabildo su favorito sistema: dar largas, entretener el tiempo, manifestar los mejores deseos y... no hacer nada (hs. 88-89).

Los antagonistas de la historia, el jesuita Juan Bautista Moga y el bibliotecario Evaristo de la Riva, ganaron de momento la partida. Moga había llegado a Sevilla en 1879, coincidiendo con el veinticinco aniversario de la definición dogmática de la Inmaculada Concepción de María e, indican Álvarez Rey y Ruiz Sánchez, se hizo pronto conocido por sus cualidades oratorias, «además de sus virtudes humanas» ${ }^{28}$. Su figura está en el centro de la polémica tanto en lo relativo al retrato como en la rivalidad entre tradicionalistas y progresistas, lo que se hizo palpable en el comportamiento

28. «Sevilla contemporánea», en Carlos Ros, dir., Historia de la Iglesia de Sevilla, Sevilla, 1992, pp. 703-708. Moga es nombrado varias veces de forma elogiosa en las Actas del Cabildo, Archivo de la Catedral de Sevilla (a partir de ahora ACS), en 1879 y 1880; en la relativa al 26 de febrero de 1880 se acuerda agradecerle su preocupación "por el celo y solicitud que hace mucho tiempo ha manifestado por el decoro y ornato de esta Sta. Iglesia» (fols. 267 v. y 268). ¿Aluden a la retirada del cuadro? 
de la Asociación de Jóvenes de la Inmaculada Concepción (Moga era su director espiritual y llegaría a ser tachada de carlista) en el jubileo mencionado en loor de la Inmaculada y en la conmemoración del segundo centenario del fallecimiento de Murillo en 1882, de la que también estuvo al frente. Los ánimos soliviantados que crisparon estas jornadas parecen aclarar las razones por las que Moga rechaza a Bécquer. Según consta en las Actas Capitulares del Cabildo hispalense (a las que me referiré por extenso más tarde), hubo diversos intentos de que el óleo se reintegrase a lo largo de 1881 con iguales consecuencias y Moga pudo haber seguido maniobrando desde la sombra. Pese a acontecer algún tiempo después de que el cuadro fuese ocultado, los planes para ejecutar la efemérides murillesca habrían comenzado antes y coincidirían con la fecha de la polémica en torno al retrato. Gestoso alude en el documento anterior a esta circunstancia y confirma su negativa a unirse al proyecto de Moga. El sentido que revistió este homenaje a Murillo dividió aún más a la sociedad sevillana: Ayuntamiento y Real Academia realizaron una serie de festejos con la aspiración de que los masones y la izquierda no llevaran a cabo una celebración laica tal y como habían anunciado; por su parte Moga y los Jóvenes de la Inmaculada Concepción quisieron convertirla en un acto católico e integrista. Al final las ceremonias resultaron deslucidas por las reclamaciones y broncas ${ }^{29}$.

La pintura estuvo pues en los muros del Salón del Almirante (lo presidía la imagen de Colón y en él se encontraban los Hijos ilustres de Sevilla) durante un periodo muy corto. Gestoso revela que Moga había hecho campaña contra Bécquer en la prensa integrista y cita un artículo en el diario católico El Siglo Futuro en donde eran rotundas las acusaciones de heterodoxia. He repasado varios años de este periódico sin suerte, pero el contenido de este posible texto no es ajeno en absoluto al sentir de la publicación, donde la condena al arte y la literatura contemporáneas son nota repetida ${ }^{30}$. Se reitera, pues, la opinión suscrita desde La Ilustración Católica.

En cuanto a Evaristo de la Riva, tal vez quepa verle solo como a una persona de poco carácter que se dejó confundir por el jesuita. De la Riva era filipense y abogado en ejercicio. Dimitió del cargo en 1884 parece que a causa de los rumores en torno a robos en la biblioteca ${ }^{31}$.

29. Lo cuenta Ma de los Santos García Felguera, La fortuna de Murillo (1682-1900), Sevilla, 1989, pp. 252-253.

30. Por ejemplo, el 21 de agosto de 1875, las obras de Espronceda y Larra son tachadas de «inmorales, escépticas, corruptoras», testimonios de la decadencia artística general («La decadencia en las Bellas Artes», por M. P. V). La perversión en los teatros, el mal ejemplo ofrecido por la narrativa y el pernicicioso influjo extranjero son otras constantes ( La moda extranjera», por M. Pérez Villamil, 1 septiembre 1875).

31. Guillén, op. cit., p. 466. 
La prensa persistió en la protesta por la retirada del lienzo, pero los resultados fueron los mismos. El satírico El Alabardero nombra, en 1880, un discurso pronunciado en el Ateneo por el Sr. Sanmartín en el que se tacha a Bécquer de poeta olvidado, lo que hace exclamar al anónimo redactor: «iAy! Sr. Sanmartín ¡créanos usted! En España no vale la pena ser literato, ¡lo que vale la pena es ser ministro! Hablen los nombres olvidados de Florentino Sanz y Gustavo Adolfo...» Poco después se pregona directamente el lance relacionado con el cuadro:

El retrato del celebrado poeta sevillano Gustavo Adolfo Bécquer, colocado entre los de hijos ilustres de Sevilla que ornan la Biblioteca Colombina, por acuerdo del Cabildo ha sido separado de aquel lugar, sin causa aparente, según afirman algunos colegas.

Nosotros hemos meditado seriamente el porqué de esta resolución y solo hemos hallado un motivo: Gustavo Adolfo Bécquer no era siquiera Doctor como Fernández-Espino ${ }^{32}$.

Más tarde vuelve al documento antes citado:

Se está formando una exposición dirigida al Cabildo Catedral en solicitud de que se reponga en su lugar el retrato del malogrado Gustavo A. Bécquer.

Nos parecen inútiles estos esfuerzos.

Comprende pronto cualquiera,

de la razón a la luz,

que en seguida se pusiera

si, en vez del de Adolfo fuera

del Cura de Santa Cruz 33 .

Tiran a matar en El Alabardero. La alusión, primero, a José Fernández Espino (cuyo retrato ingresa en la galería en 1877), uno de los discípulos de Alberto Lista y profesor de Literatura en la Universidad, lleva la pulla hacia los lugartenientes de la escuela poética sevillana y, en general, hacia la generación anterior al propio Bécquer, que detentaba aún el poder político

32. El Alabardero, 58, 28 febrero 1880, [p. 2]; y 70, 22 mayo 1880, [p. 4]. José F. Sanmartín y Aguirre es autor de Baladas y cantares (1870).

33. 76, 26 junio 1880, [p. 4]. Estos artículos de El Alabardero fueron localizados en el proceso de un trabajo de investigación sobre la recepción de Bécquer en Sevilla en el que colaboraron, bajo mi dirección, los siguientes alumnos de la Facultad de Filología (Universidad de Sevilla): Víctor Manuel López Cabrera, Purificación Jurado Domínguez, José Manuel López Martín, Jorge Mojarro Romero y Ana Belén González Pérez. 
y cultural. En cuanto al fanático cura y guerrillero carlista Manuel Ignacio Santa Cruz Loidi, su mención es oportuna dada la filiación carlista del Padre Moga, cuya intervención fue tan definitiva en el derrotero del caso. La ironía crítica sigue en otro breve del 11 de agosto, glosa de un inserto aportado en otro periódico, sin más datos: "Parece que un hijo del célebre poeta sevillano Gustavo Adolfo Bécquer va a entrar en la Compañía de Jesús», a lo que añaden: "Creemos que después de esta agradable noticia no se ofrecerá dificultad en la Colombina para colocar el retrato de su padre» ${ }^{34}$.

Pero la lucha no había terminado. La consulta de las Actas Capitulares ofrece la historia desde el punto de vista del cabildo eclesiástico y da noticia de nuevos intentos en pro de la restitución de la pintura. El 11 de febrero de 1881 se hace constar una petición realizada por varios artistas de que se colocase el retrato de Gustavo en las salas de la Biblioteca. Nada dicen las Actas del contenido de esta demanda, pero Joaquín Guichot la resume en otro lugar: "una solicitud firmada por la casi totalidad de los hombres que en Sevilla se dedican al cultivo de las letras y de las artes -sin exclusión de partido alguno político o de escuela filosófica-, suplicando a la Ilma. Corporación se sirviese disponer la colocación del retrato del ilustre poeta Gustavo Adolfo Bécquer entre los de los sevillanos ilustres que ornan los muros de la Biblioteca Colombina» ${ }^{35}$. En las Actas no hay rastro de una primera solicitud en 1880 (año del requerimiento colectivo organizado por Gestoso), por lo que caben dos posibilidades: bien no pasó a la consideración del Cabildo, bien se trata de esta que ahora se discute (lo que confirmaría las razones del cansancio de Gestoso ante la lentitud excesiva e injustificada del proceso). Se volvió sobre la materia el día 21 (el bibliotecario realizó un informe que no se recoge), y la porfía se aplazó para una reunión posterior, el 25 de febrero de 1881. Esta vez el acta sí traslada las conversaciones: se argumentó sobre la conveniencia de contar con el retrato de Bécquer entre los de sevillanos ilustres $y$, tras una intensa controversia, quedó pendiente de votación, resultando un empate: seis votos a favor, seis en contra, una abstención ${ }^{36}$. Repetida hasta tres veces con idéntico desenlace,

34. 89, 11 agosto 1880, [p. 2].

35. Historia de la ciudad de Sevilla y pueblos importantes de su provincia, Sevilla, 1886, t. VI, p. 220.

36. Esta reunión fue convocada "con llamamiento», es decir, avisando por escrito de forma explícita a cada uno de los miembros por su cargo en el Cabildo Metropolitano. Se pretendía así que la asistencia a la reunión fuese masiva, porque parece que eran pocos los que acudían con regularidad. Copio el fragmento del acta relativo a Bécquer: «Viernes, 25 de febrero de 1881. / Presidiendo el Sr Arcediano. Asistieron Los Sres. Maestrescuela, Capellán Mayor, Jiménez Blasco, Ruiz López, Arroquia, La Riva, Doctoral, Díaz de Rueda, Ruiz García, Cansino, Rivera y el secretario, Antonio Rodríguez y Montero. / [Al margen: 
la determinación final se postergó para una ulterior convocatoria. El 3 de marzo hubo un amplio debate en torno a la colocación del «retrato de un autor moderno", haciendo clara la división del Cabildo, cuyos miembros defendieron sentires opuestos. Cayetano Fernández y Cabello, que ocupaba la dignidad de Chantre, presentó un escrito de acuerdo que terminó siendo aprobado:

$1^{\circ}$. Que se apruebe el dictamen del Sr. Bibliotecario capitular [no figura en el acta] con la única modificación de que no ha lugar a deliberar por ahora, encargándose el mismo Sr. Bibliotecario que para su día, y por los medios que estén a su alcance, continúe en la averiguación de las circunstancias que pueden hacer a la memoria del Sr. Bécquer acreedor al honor que se solicita.

$2^{\circ}$. Que se ponga al margen o a continuación del memorial presentado sobre este asunto el decreto siguiente: Este Cabildo Metropolitano tiene adoptada, para la colocación de retratos en su Biblioteca, la inviolable regla de que ninguno sea colocado allí ínterin no conste que la importancia y la excelencia de los escritos del sujeto que representa hacen a su nombre digno de las honras de la inmortalidad o memoria de los venideros. En tal virtud el Cabildo acordará gustoso la colocación del retrato del Sr. Bécquer tan luego como, por los medios que tiene establecidos y no por otros, llegue al convencimiento de que el autor de quien se trata es acreedor a la honra que para el mismo se pretende. En esta forma de proceder cree el Cabildo que, sin desestimar

Informe del Sr. Bibliotecario] / Se dio lectura a la cédula de citación y enseguida al informe del Sr. Bibliotecario acerca de la colocación del retrato del escritor D. Gustavo Adolfo Bécquer entre los que figuran en la denominada Colombina. Discutido el asiento ampliamente (salió de la sala el Sr. La Riva), como no hubiera conformidad de parecer, se puso a votación si se aprobaba el informe, resultando seis votos en favor y seis en contra, habiéndose abstenido de votar el Sr. Maestrescuela. Repitióse la votación hasta tercera vez, dando el mismo resultado, y en esa consecuencia se acordó se dé citación para tratar el mismo asunto en la primera sesión ordinaria» (ACS, fols. 15-15v.). Anoto los nombres de los integrantes del Cabildo sevillano en 1881: Arcipreste, Ramón Mauri; Arcediano, Fernando Olmedo; Chantre, Cayetano Fernández; Maestrante, Eusebio Tarancón; Tesorero, Manuel Marrón y Aguilar; Capellán Mayor de la de San Fernando, Servando Arbolí; Canónigos, Genaro Guillén Calomarde, Francisco Parra y Ramos, Tomás Jiménez Blasco, Antonio Rodríguez Montero, Celestino del Parque, Francisco Cabero, Felipe Ruiz y López, Gerónimo Pagés, Domingo Arroquia, Evaristo de la Riva, Antonio Ruiz Cabal (doctoral), Agustín Sánchez Torres (Lectoral), José María Vidal y Cruz, Vicente Juan García Iborra (Penitenciario), José María Ruiz, Miguel Torres y Daza, Marcelo Spínola y Maestre (Obispo auxiliar), Antonio Cansino, Bernabé González y Enrique Rivera. Secretario: Antonio Rodríguez Montero. (Fuente: M. Gómez Zarzuela, Guía de Sevilla, Sevilla, 1881, p. 329). 
los loables deseos de los Sres. Exponentes, atiende, como es justo, al propio tiempo, al carácter de prudencia, y también de espontaneidad, que deben revestir los actos de una Corporación celosa de su dignidad.

$3^{\circ}$. Y por último, que para evitar en adelante conflictos de este linaje, en lo sucesivo no se admita por la Secretaría Capitular, ni se dé curso de ninguna otra manera, a los memoriales de personas particulares, extrañas a nuestra corporación en solicitud de que se haga u se omita alguna cosa en nuestra Galería o en sus dependencias que tenga carácter público, por creerlos altamente ofensivos a la ilustración y celo con que el Excmo. Cabildo mira y ha mirado siempre los intereses que están bajo de su legítima custodia ${ }^{37}$.

Tras una pausa, se dio paso a la elección: la propuesta del chantre es aprobada por doce votos contra cuatro y seis abstenciones (Maestrescuela, Vidal, Torres Daza, D. Bernabé González, Lectoral y Rivera). Algunos capitulares solicitaron que se hiciese constar su voto negativo, lo que no procedió al tratarse de consulta secreta. El asunto pareció así quedar zanjado a la espera de aportaciones al caso.

La norma que se cita en el punto segundo de las actas se refleja en la documentación relativa a la incorporación de otros cuadros a la galería. No fue exclusiva, pues, para Bécquer. En el Anuario publicado por la CapitularColombina el año 1877, y tras señalar la llegada de cuatro nuevos -entre ellos los de Gabriel García Tassara, pintado por Manuel Wssel, y José Fernández Espino- se persevera en recordarla: «que no se admitan retratos sino de aquellas personas que tengan, por sus obras, asegurado lugar honroso en la posteridad». De Tassara se decía: «escritor distinguido, eminente poeta y hábil diplomático». En cuanto a Fernández Espino: «hablista muy correcto, catedrático erudito, director dignísimo de la Academia Sevillana, elocuente diputado a cortes, celoso director de Instrucción Pública», y se ańade: «Tuvo a gloria profesar y defender siempre muy sanos principios en el orden

37. ACS, fols. 16-16v. Los asistentes a esta reunión fueron los que siguen: Arcediano, Chantre, Maestrescuela, Capellán Mayor, Calomarde, Jiménez, Parque, Cabero, Parra, Ruiz López, La Riva, Doctoral, Lectoral, Díaz de Rueda, Vidal, Penitenciario, Ruiz García, Torres Daza, González (D. Bernabé), Cansino, Rivera y el secretario, Antonio Rodríguez y Montero. Cayetano Fernández, abogado y profesor de literatura y música en Sevilla, ingresó en la Congregación de San Felipe Neri y redactó el volumen Fábulas ascéticas, muy difundido a lo largo del siglo en los establecimientos de enseńanza. Se trasladó luego a Madrid, donde fue preceptor del príncipe D. Alfonso y miembro de la Academia de la Lengua. En 1867 fue nombrado Chantre de la Iglesia sevillana y actuó también como bibliotecario de la Colombina. 
religioso, artístico y filosófico» ${ }^{38}$. En distintas ocasiones el bibliotecario pide permiso para aceptar un lienzo y así se anota en el acta; no hay tal súplica en lo referente a Bécquer antes del 11 de febrero de 1881.

Finalmente el cuadro no se recolocó, por lo que Gestoso escribió en junio de 1885 una carta al eclesiástico Servando Arbolí, bibliotecario de la Colombina en sustitución de De la Riva, instándole a su devolución "para darle el destino que juzgue más oportuno». Arbolí contesta de inmediato procediendo a dar las órdenes necesarias para que ésta se efectúe. Gestoso lo envió en depósito a continuación a la Biblioteca de la Sociedad Económica de Sevilla ${ }^{39}$.

Gestoso resumió estos avatares en una carta a su amigo Achille Fouquier, traductor de Bécquer al francés y estudioso del folklore español, inserta en un número extraordinario de la barcelonesa La Ilustración Artística (27 de diciembre de 1886), homenaje a Gustavo Adolfo compuesto con el objetivo de obtener fondos para trasladar sus restos mortales a Sevilla (tampoco entonces tuvo suerte en su tierra, esta vez a causa de la oposición del claustro de la Universidad de Sevilla: no se verificaría hasta la primavera de 1913). En sus recuerdos, uno y otro empeño se confunden, pues hubo que enfrentar las mismas dificultades en la Universidad que antes en la Colombina. Así lo subraya en la carta a Fouquier con el fin de que la posteridad conozca la trama:

Junto al entusiasmo de la juventud, a sus nobilísimos impulsos, a sus esfuerzos y generosa lucha para tributarle un homenaje de gloria, aparecen también las sordas y mezquinas pasiones de políticos sin corazón, que, incapaces de sentir y menos aun de comprender los vuelos de aquel espíritu, pretenden hallar con el escalpelo de la fría razón motivos de censura para manchar su memoria [...]. [N]iégase un asilo a sus huesos alegando fútiles pretextos, y llega la pasión hasta el extremo de lanzar gravísimas acusaciones en el concepto religioso, para atraer la odiosidad de algunos a los sacrificios desinteresados de tantos hombres. [...] [P]ido al cielo aleje

38. Cayetano Fernández, Anuario de la Biblioteca Colombina... 1877, Sevilla, 1878, pp. 32 y 33.

39. De historia sevillana, hs. 89-90. Gestoso anota la fecha 15 de junio; según precisa Juan Guillén a la vista de la carta, que se conserva, está fechada el 12 (Guillén, p. 476). Servando Arbolí y Faraudo doctor en Cánones y Teología, eclesiástico, Licenciado en Derecho, fue profesor en el Seminario de San Cecilio, en Granada, hasta que, en 1876, pasó a Sevilla. Capellán Mayor de San Fernando, catedrático del Seminario, Vicario general castrense, Protonotario Apostólico, Bibliotecario de la Colombina, miembro de la Real Academia Sevillana de Buenas Letras (de la que fue director) y de la de Bellas Artes. 
de mi mente el pensamiento de oscurecer la memoria de los que fueron, con suposiciones nacidas de la pasión religiosa o política, mala consejera siempre ${ }^{40}$.

Mientras Gustavo era negado por la iglesia y el poder cultural, su prestigio crece entre los escritores y el público. No insistiré en ello, pero la prensa hispalense ofrece ejemplos del amor al poeta en imitaciones y glosas de las rimas desde 1871, al mismo tiempo que se estudia su obra, se descubren nuevos datos de su biografía y salen a la luz textos inéditos.

\section{LA CALLE «BÉCQUER»}

Las diligencias de los seguidores de Gustavo Adolfo dieron sin embargo algún fruto, aunque más modesto: en 1881 se rotula con su apellido una calle en Sevilla. Situada frente a la zona de la Barqueta, lugar al que era asiduo en su adolescencia y que evoca en la carta III (Cartas desde mi celda), está la vía que en siglos pasados había recibido diversos nombres: Muro, Muro de la Macarena, Muro de los Escoberos y Muro de la Barqueta, área marginal que se encontraba en proceso de reurbanización ${ }^{41}$. La ubicación no parece haber sido del agrado de sus defensores, pues en una crónica local de El Baluarte (4 de mayo de 1886) se califica como desafortunada. Para el redactor la elección era índice del poco aprecio que los políticos, proclives a favorecerse a ellos mismos -subraya-, tenían por los valedores de la cultura sevillana:

$[\mathrm{P}]$ udo elegirse, para decorarla con el nombre del famoso varón, alguna calle que no alterase las direcciones comerciales ni perjudicase intereses mercantiles.

Las de Bécquer y Torrigiano -que algo más valieron que el Sr. Pellón- están allí en la Resolana, para ilustración del barrio de la Macarena [...]

La calle dedicada a Manuel Puente y Pellón, alcalde de Sevilla en cortos mandatos de 1872, 1874, 1881 y 1886, es una de las principales arterias del

40. En este artículo Gestoso copia la partida bautismal de Gustavo, así como da a conocer el texto de la composición que comienza La gota de rocío que en el cáliz.

41. A. Collantes de Terán, J. Cruz Villalón, R. Reyes Cano, S. Rodríguez Becerra, dirs., Diccionario Histórico de las calles de Sevilla, Sevilla, 1993, t. I, pp. 138-139. Esta calle llevó, entre 1935 y 1949, el nombre completo de «Gustavo Adolfo Bécquer». 
centro de la ciudad, mientras las de Bécquer y el escultor florentino Pietro Torrigiano, fallecido en Sevilla hacia 1528, quedaban muy lejos de la zona noble.

No tuvo suerte Gustavo Adolfo Bécquer en Sevilla. Pero pasan los ańos y se olvidan los trabajos, las negativas y las acusaciones; aquellos que, desde la política, la iglesia u otros estamentos de poder, le rechazaron se rinden al peso de su popularidad y de la creciente aceptación crítica de su obra, puede que sin más criterio que la disciplina a la que obliga la opinión pública. Para las letras hispalenses, tan lastradas por el conservadurismo católico y el formalismo dictado por la segunda escuela poética sevillana (heredera de las maneras de Herrera, Rioja, Fray Luis... a través de la educación de los Alberto Lista, José Fernández Espino y Francisco Rodríguez Zapata) tal vez fue prematuro elevar a Gustavo al altar de la galería de sevillanos ilustres. Lo cierto es que si la colocación del cuadro en la Colombina fue tarea complicada, empresas tales como la erección del monumento que hoy se contempla en el Parque de María Luisa o el traslado de los restos mortales de Gustavo Adolfo y Valeriano Bécquer desde Madrid a Sevilla tuvieron que esperar tanto que los jóvenes de antańo eran ya viejos. De hecho, fue necesario el transcurso de una generación para que pudiesen llevarse a cabo. Pese a que solo me ocupo ahora del caso de la Colombina, es difícil separar todos estos acontecimientos. Vuelvo a ceder la palabra a Gestoso, para quien la oposición y la desidia fue general; hubo que superar «el fanatismo y los prejuicios», recalca, para lograr una resolución feliz:

No debemos callarlo. Necesario ha sido que ocurriese, en tan largo lapso de tiempo, un cambio radical en las ideas, en los sentimientos de muchas gentes, en el gusto literario, y hasta en la influencia religiosa, la cual, hoy tolerante, no da asenso a insanos fanatismos, predominantes en nuestros días juveniles. Varones ilustres por sus méritos literarios juzgaban a Bécquer, sin duda no conociéndolo a fondo -y sea esto dicho en su descargo- como un poetilla incipiente. Otros, encarińados con la forma clásica, desdeñábanlo, animados de funesto exclusivismo; y no faltaban quienes vislumbraban, en la prosa y en los versos becquerianos, ciertos dejos de escéptica heterodoxia, inadmisible para todo creyente y buen católico. Las amarguras y desalientos del poeta, expresados, a veces, bajo la forma de la duda, eran tenidos, por aquellos severos críticos, ¡como innegables y serias definiciones de su impiedad! No es, pues, extraño que su retrato hubiese sido rechazado por determinada Corporación religiosa, que se hubiesen creado dificultades para el transporte e inhumación de sus restos 
en esta ciudad, y que a cada momento surgiesen inconvenientes que dificultaban las gestiones de la primera Comisión nombrada para enaltecer la memoria de Bécquer. De entonces acá [1916], ¡qué cambio en las ideas! [... $]^{42}$.

\section{BREVE CODA: LECTURA ICONOGRÁFICA DEL CUADRO}

Del retrato de Bécquer realizado por Salvador Sánchez Barbudo (Jerez de la Frontera, Cádiz, 1857-Roma, 1917) ${ }^{43}$ hay tres versiones; dos de mano de Sánchez Barbudo y parece que igual fecha: 1879. Una es la destinada a la Colombina (colgada según Gestoso hacia finales del 79 o principios del 80); otra ingresó en el patrimonio de la Universidad de Sevilla en 1879, sin más precisiones. Gestoso afirma que fue idea suya la factura de la versión de la Universitaria, que donó al director del establecimiento, Juan José Bueno, con tal fin. Esta obra, instalada primero en el antiguo edificio de la Universidad en la calle Laraña, pasó luego al actual Rectorado, en la Fábrica de Tabacos. No es fácil averiguar cuál fue pintada antes, porque el mismo Gestoso da explicaciones distintas. Los gastos de la Universitaria fueron costeados por Manuel Ma Santa Ana. Me pregunto cuál fue la verdadera intervención del bibliófilo y coleccionista de arte Juan José Bueno en todo este proceso, ya que -según adelanté-en su cargo de regidor del Ayuntamiento había trabajado con su gran amigo, el oficial Velázquez y Sánchez, en el crecimiento de la galería Colombina y había solicitado la ayuda desinteresada de varios pintores con la pretensión de honrar a profesores, artistas y otros personajes de importancia histórica. Más tarde, como jefe de la Biblioteca Universitaria, se aplica con igual sentido y hace acopio de una colección similar a la Colombina, para lo que requiere varios cuadros. Hay constancia documental de estas peticiones. ¿Exagera Gestoso su protagonismo? ${ }^{44}$

42. Homenaje rendido por la ciudad de Sevilla a sus ilustres hijos Gustavo Adolfo y Valeriano Bécquer, Sevilla, 1916, p. 2.

43. Ingresó en 1875 en la Escuela Provincial de Bellas Artes de Sevilla. Se traslada a Madrid en 1879 para estudiar y participa en las Exposiciones Nacionales. Marcha en 1882 a Roma, donde fue discípulo de José Villegas Cordero, y comienza su producción pictórica más conocida (como La puérpera y El café). Sus obras tuvieron gran acogida entre los marchantes y compradores extranjeros. Viaja por toda Italia y se instala finalmente en Roma, aunque reside largas temporadas en Venecia (C. González y M. Martí, Pintores españoles en Roma (1850-1900), Barcelona, 1996, pp. 201-205).

44. Una historia en parte distinta cuenta Gestoso en "Carta abierta de un Licenciado sevillano a los hermanos Quintero", La Andalucía Moderna, 8 mayo 1910. Aquí el cuadro de la Universitaria fue el primero: «Un entusiasta sevillano admirador de Bécquer, de los que mayor parte había tomado en los homenajes que se le tributaron [habla de él mismo], concibió el propósito de que el retrato del poeta luciese en las colecciones iconográficas de 
FAMA Y FORTUNA DE GUSTAVO ADOLFO BÉCQUER

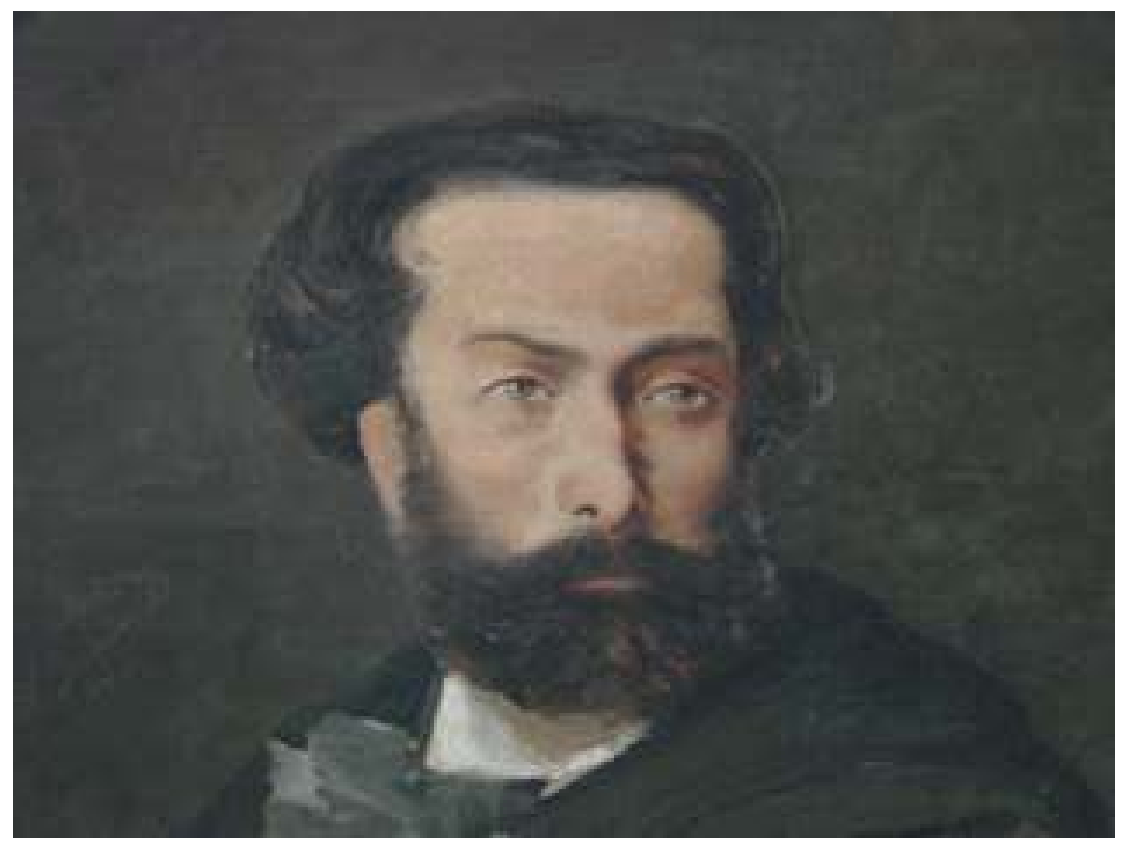

Retrato. «Gustavo Adolfo Bécquer», por Salvador Sánchez Barbudo, detalle (Biblioteca General, Universidad de Sevilla) 
Juan José Bueno, que fue protector de Gustavo Adolfo Bécquer en sus comienzos, le distingue al entender que merecía figurar en la galería de la Universidad. A diferencia de lo que luego ocurrirá con el traslado de sus restos (el Rectorado se negó a que fuesen inhumados en el panteón de sevillanos ilustres, propiedad suya), aquí se mostró más liberal que el Cabildo catedralicio, si bien es cierto que, al destinarse el lienzo a las salas de la biblioteca, parece que la decisión corrió de parte de su jefe, es decir, Bueno.

Las dos versiones siguen idénticas pautas en su ejecución; las distingue el medio elegido para inscribir el nombre del poeta: una orla en óvalo en torno al busto en cuya parte inferior se lee G. A. Bécquer (Universitaria) y una tarjeta en la base con la inscripción "Gustavo A. Bécquer / Insigne poeta / Nació en Sevilla el 17 de febrero de 1836 / Murió en Madrid el 22 de diciembre de 1870» (Colombina). Restaurado recientemente, este último puede visitarse en la sala de acceso a la Biblioteca Capitular-Colombina. El de la Universitaria no está a la vista del público cuando redacto este ensayo (en 2007), sino almacenado en un depósito.

En cuanto a la que cabe señalar como tercera versión, se encuentra en la Sociedad Económica de Amigos del País y es de distinta mano. Fue encargada

hijos ilustres de esta ciudad que adornan los muros de las Bibliotecas Universitaria y Capitular Colombina, a cuyo fin interesó al señor Manuel María Santana para que costease el que había de figurar en la primera de las citadas bibliotecas, el cual prestóse gustoso, y bien pronto el artístico busto de Gustavo Adolfo, debido al peritísimo pintor Salvador Sánchez Barbudo, enriqueció el salón de lectura de dicho Establecimiento. El mencionado artista prestóse también, con la mayor generosidad, y a ruego de la misma persona, a hacer una copia del retrato original, que se destinaba a la Colombina, y en efecto, durante unos días, allá pudo vérsele, formando parte de la colección». En torno a Juan José Bueno y su contacto con Gustavo Adolfo Bécquer, R. Pageard, Bécquer. Leyenda y realidad, op. cit., pp. 52, 54, 55, 119-121, y M. Palenque, «El autógrafo de la carta de Gustavo Adolfo Bécquer a Juan José Bueno y otros documentos inéditos relativos a su familia» y "Sigamos las claras huellas: el bibliófilo sevillano Juan José Bueno y Le-Roux», en P. Bolaños Donoso, A. Domínguez Guzmán y M. de los Reyes Peña, coords., "Geh hin und lerne». Homenaje al Profesor Klaus Wagner, Sevilla, 2007, vol. 1, pp. 355-380. El nombre de Bueno sale también en las cartas que editan J. Urbina y J. Rubio Jiménez, «La correspondencia de Narciso Campillo en la Biblioteca Nacional. Documentos relacionados con Gustavo Adolfo Bécquer y su entorno", El Gnomo. Boletín de Estudios Becquerianos, 12-13, 2004, pp. 11-91.

Como ya antes comenté en el texto, además de las galerías de la Colombina y la Universitaria (puede consultarse su catálogo en www.patrimonio.us.es), el duque de Montpensier reunió una propia, ahora en el Ayuntamiento hispalense (al respecto V. Lleó Cañal, La Sevilla de los Montpensier: segunda corte de España, Sevilla, 1997, pp. 79-81 y 83). Asimismo, en la Academia de Buenas Letras, en la de Bellas Artes y en la Sociedad Económica de Amigos del País hay lienzos de parecida factura y propósito coincidente. En ocasiones se trata de copias de un primer retrato: en las ACS se leen varias peticiones de estos centros para reproducir piezas propiedad de la Colombina. 
por Gestoso a José Macías tras la vuelta de la original a la Colombina ${ }^{45}$.

Reproduzco en estas páginas el retrato de la Universitaria. Rafael Montesinos ofreció una copia del colombino en Bécquer. Biografía e imagen y comenta que lo cree inspirado en el grabado que figura al frente de la segunda edición de las Obras del poeta ${ }^{46}$. La pintura da una imagen de Gustavo poco difundida, que contrasta con la más conocida obra de Valeriano Bécquer, y presenta a un hombre maduro, cuyo gesto es grave y firme, de nariz más prominente, ojos más pequeños, claros y acuosos, con una mirada profunda e intensa, que -sesgada- se pierde en el infinito y huye de la contemplación directa del espectador. Parece una mixtura entre el cuadro de Valeriano (de estilo romántico, misma indumentaria: capa espańola, igual insistencia en la mirada) y el grabado de la mencionada segunda edición (que se basa en la foto de Bécquer que Montesinos muestra asimismo en la página 267 de su libro; sobre todo por el peinado y la barba; tal vez por la lazada al cuello).

Es curioso que gran mayoría del público no identifique en la efigie de Sánchez Barbudo a Gustavo, a quien reconoce espontánea y claramente en el retrato trazado por su hermano. Lo que, de cualquier modo, no pone en tela de juicio la calidad del lienzo del pintor jerezano.

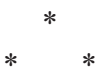

Recobrando el hilo de la historia matriz de este ensayo, los escollos en la recepción de Bécquer en Sevilla no fueron un fenómeno aislado, sino que -como he intentado exponer- tuvieron correlato en el resto del país. La producción becqueriana fue leída a partir de distintas ópticas, y, sobre todo desde las filas católicas, fue sentenciada como perniciosa para la poesía española. Las galerías o colecciones de retratos responden a un proyecto de vindicación de la historia y de la cultura, y constituyen una defensa de la tradición que tuvo una indudable base política. Para los más jóvenes, incorporar a Bécquer a esta tradición vendría a suponer un revulsivo necesario frente al conservadurismo de sus mayores, al mismo tiempo que simbolizaba el inicio de una nueva y moderna tradición bética.

(Sevilla, mayo 2007)

45. Así lo cuenta Gestoso. La Sociedad Económica se encuentra clausurada en la fecha de elaboración de este ensayo, por lo que no he tenido acceso a esta versión.

46. Op. cit., p. 334. Francisco de Laiglesia no menciona este cuadro en Bécquer (sus retratos) (Madrid, 1922). Cuando corrijo pruebas, añado un nuevo título en el que se cotejan diferentes imágenes de G. A. Bécquer: J. Rubio Jiménez, Pintura y literatura en Gustavo Adolfo Bécquer (Sevilla, 2006). 
